\title{
Correction to: Multidimensional Poverty of Children in Mozambique
}

\author{
Kristi Mahrt ${ }^{1} \cdot$ Andrea Rossi $^{2} \cdot$ Vincenzo Salvucci $^{3} \cdot$ Finn Tarp $^{3,4}$ \\ Published online: 23 April 2020 \\ (C) UNU-WIDER 2020
}

\section{Correction to: Child Indicators Research https://doi.org/10.1007/s12187-019-09696-6}

The article Multidimensional Poverty of Children in Mozambique, written by Kristi Mahrt, Andrea Rossi, Vincenzo Salvucci and Finn Tarp, was originally published electronically on the publisher's internet portal on 10 March 2020 without open access. With the author(s)' decision to opt for Open Choice the copyright of the article changed on April/2020 to (C) The Author(s) 2020 and the article is forthwith distributed under a Creative Commons Attribution 4.0 International License (https://creativecommons. org/licenses/by/4.0/), which permits use, sharing, adaptation, distribution and reproduction in any medium or format, as long as you give appropriate credit to the original author(s) and the source, provide a link to the Creative Commons licence, and indicate if changes were made.

The original article has been corrected.

The online version of the original article can be found at https://doi.org/10.1007/s12187-019-09696-6

Vincenzo Salvucci

vincenzo.salvucci@gmail.com

Kristi Mahrt

k.mahrt@cgiar.org

Andrea Rossi

arossi@unicef.org

Finn Tarp

finn.tarp@econ.ku.dk

1 IFPRI, Washington, DC, USA

2 UNICEF East Asia and Pacific Regional Office, Bangkok, Thailand

3 University of Copenhagen, Copenhagen, Denmark

4 UNU-WIDER, Helsinki, Finland 
Open Access This article is licensed under a Creative Commons Attribution 4.0 International License (https://creativecommons.org/licenses/by/4.0/), which permits use, sharing, adaptation, distribution and reproduction in any medium or format, as long as you give appropriate credit to the original author(s) and the source, provide a link to the Creative Commons licence, and indicate if changes were made. The images or other third party material in this article are included in the article's Creative Commons licence, unless indicated otherwise in a credit line to the material. If material is not included in the article's Creative Commons licence and your intended use is not permitted by statutory regulation or exceeds the permitted use, you will need to obtain permission directly from the copyright holder. To view a copy of this licence, visit http://creativecommons.org/licenses/by/4.0/

Publisher's Note Springer Nature remains neutral with regard to jurisdictional claims in published maps and institutional affiliations. 